\title{
Phosphorus Fertilizer Rate for Fresh Market Potato Cultivars Grown in Tropical Soil with Low Phosphorus Availability
}

\author{
Adalton M. Fernandes ${ }^{1}$ - Rogério P. Soratto ${ }^{2}$
}

Published online: 16 March 2016

(C) The Potato Association of America 2016

\begin{abstract}
Knowledge on phosphorus (P) response of main potato cultivars is essential to rational fertilization management and maximize yield, mainly in tropical soils that usually have low $\mathrm{P}$ availability. An experiment was conducted to evaluate the effect of $\mathrm{P}$ fertilization rates $(0,125,250,500$, and $1000 \mathrm{~kg} \mathrm{P}_{2} \mathrm{O}_{5} \mathrm{ha}^{-1}$ ) on leaf nutrient concentrations, tuber yield and size distribution, as well as applied P-use efficiency (APUE) in the potato cultivars Agata and Mondial. The results indicated that it is not necessary to evaluate the P-nutritional status and adjust $\mathrm{P}$ recommendations on a cultivar basis because $\mathrm{P}$ fertilization resulted in similar increases in the leaf $\mathrm{P}$ concentration of both cultivars, and the cultivars responded to the same $\mathrm{P}$ rate $\left(500 \mathrm{~kg} \mathrm{P}_{2} \mathrm{O}_{5} \mathrm{ha}^{-1}\right)$. However, Mondial had a higher APUE and was more responsive than Agata to the same $P$ rate. A leaf $P$ concentration of $2.9 \mathrm{~g} \mathrm{~kg}^{-1}$ was superior to $2.5 \mathrm{~g} \mathrm{~kg}^{-1}$ as the lower limit of the $\mathrm{P}$ sufficiency range for Agata and Mondial.
\end{abstract}

Resumen El conocimiento de la respuesta al fósforo $(\mathrm{P}) \mathrm{de}$ las principales variedades de papa, es esencial para un manejo racional de la fertilización y maximizar el rendimiento, principalmente en suelos tropicales que usualmente tienen baja disponibilidad del P. Se condujo un experimento para evaluar el efecto de los niveles de fertilización con $\mathrm{P}\left(0,125,250,500, \mathrm{y} 1000 \mathrm{~kg} \mathrm{P}_{2} \mathrm{O}_{5} \mathrm{ha}^{-1}\right)$ en concentraciones

Rogério P. Soratto

soratto@fca.unesp.br

1 Center for Tropical Roots and Starches (CERAT), São Paulo State University (UNESP), P.O. Box 237, Botucatu, SP 18610-307, Brazil

2 Department of Crop Science, College of Agricultural Sciences, São Paulo State University (UNESP), P.O. Box 237, Botucatu, SP 18610-307, Brazil del nutriente en la hoja, rendimiento de tubérculo y distribución de tamaños, así como la eficiencia del uso del P aplicado (APUE) en las variedades de papa Agata y Mondial. Los resultados indicaron que no es necesario evaluar el estatus del $\mathrm{P}$ nutricional ni ajustar las recomendaciones de $\mathrm{P}$ con base a la variedad, porque la fertilización con $\mathrm{P}$ dio como resultado incrementos similares en la concentración de $\mathrm{P}$ en la hoja de ambas variedades, y éstas respondieron a la misma concentración del $\mathrm{P}\left(500 \mathrm{~kg} \mathrm{P}_{2} \mathrm{O}_{5} \mathrm{ha}^{-1}\right)$. No obstante, Mondial tuvo una APUE más alta y respondió más que Agata a un mismo nivel de P. Una concentración foliar de $\mathrm{P}$ de $2.9 \mathrm{~g} \mathrm{~kg}^{-1}$ fue superior a $2.5 \mathrm{~g} \mathrm{~kg}^{-1}$ como el límite más bajo del rango de suficiencia de $\mathrm{P}$ para Agata y Mondial.

Keywords Solanum tuberosum - Applied P-use efficiency · Foliar diagnosis $\cdot$ Tuber number $\cdot$ Tuber size $\cdot$ Tuber yield

\section{Introduction}

Potato (Solanum tuberosum L.) is a major food source worldwide. Because of the high efficiency of food and calories produced per area, potato cultivation has been increasing, particularly in tropical lands and developing countries (FAOSTAT 2015), to ensure high utilization of areas for food production. However, the potato crop has a high nutrient demand (Fernandes et al. 2011a) due to its short development cycle and high yield.

Phosphorus (P) is important in energy transfer processes in cells, respiration and photosynthesis (Marschner 2012; Rosen et al. 2014) and is an essential element for plant growth (Tóth et al. 2014). Phosphorus plays an important role in starch metabolism in potato plants and is required in relatively large amounts by these plants for the phosphorylation of starch during the tuber bulking phase 
(Houghland 1960). An adequate $\mathrm{P}$ supply for potato crops is fundamental for increasing the number of tubers per plant (Freeman et al. 1998; Rosen and Bierman 2008) and the size of the tubers (Dubetz and Bole 1975; Freeman et al. 1998).

Potato crops have a low capacity for $\mathrm{P}$ uptake, especially in soils with low P availability (Hopkins et al. 2014; Thornton et al. 2014). This is the case for most tropical and subtropical soils in which a substantial proportion of the $\mathrm{P}$ applied to the soil becomes unavailable for plant uptake (Ramaekers et al. 2010). In these soils, a large proportion of $P$ is bound to soil constituents, forming complexes that have limited bioavailability, especially $\mathrm{Al}$ and Fe oxides and clay minerals such as kaolinite (Valladares et al. 2003; Ramaekers et al. 2010; Tóth et al. 2014). Thus, in most tropical regions, a major factor that limits potato yield is low P availability (Fontes et al. 1997; Ramaekers et al. 2010; Soratto et al. 2015). Furthermore, P is the nutrient that provides the highest yield response in potato crops (Boock and Freire 1960; Freeman et al. 1998; AlvarezSánchez et al. 1999; Nava et al. 2007; Rosen and Bierman 2008; Luz et al. 2013).

In Brazil, the $\mathrm{P}$ fertilizer recommendations for potatoes range between 50 and $420 \mathrm{~kg} \mathrm{P}_{2} \mathrm{O}_{5} \mathrm{ha}^{-1}$; these recommendations are based solely on the concentration of available $\mathrm{P}$ in the soil (Lorenzi et al. 1997; Fontes 1999). However, studies have shown that the potato cultivars Agata and Mondial, which are among the most widely planted in Brazil for the fresh tuber market, take up different amounts of P (Fernandes et al. 2011a), use different strategies for handling $P$ deficiency in nutrient solution (Fernandes et al. 2014) and respond differently to P supply under greenhouse conditions (Soratto et al. 2015). It remains unknown whether the Agata and Mondial cultivars respond differently to $\mathrm{P}$ fertilization under field conditions and whether they require $\mathrm{P}$ at rates that differ from those currently recommended to fully express their yield potential.

The objective of this study was to evaluate the effect of the fertilizer $\mathrm{P}$ rate on the leaf nutrient concentrations, tuber yield and size distribution, and the applied P-use efficiency (APUE) of Agata and Mondial potato cultivars grown in tropical soil with low $\mathrm{P}$ availability.

\section{Materials and Methods}

Field experiments were conducted in potato production areas located in São Paulo State, southeastern Brazil, during two fall-winter seasons. In 2011, the experiment was performed near Avaré ( $48^{\circ} 47^{\prime} \mathrm{W} ; 23^{\circ} 02^{\prime} \mathrm{S}$ and $744 \mathrm{~m}$ a.s.1.) in an area that was previously grass pasture (Urochloa decumbens Stapf.) and in 2012, the experiment was performed near Taquarituba $\left(49^{\circ} 09^{\prime} \mathrm{W} ; 23^{\circ} 38^{\prime} \mathrm{S}\right.$ and $676 \mathrm{~m}$ a.s.1.) in an area previously cultivated with soybean [Glycine $\max (\mathrm{L}$.) Merr.].
The soil of both experimental areas was classified as a clay Oxisol with a low $\mathrm{P}_{\text {resin-extractable }}$ content (lower than $25 \mathrm{mg} \mathrm{dm}^{-3}$ ) (van Raij et al. 1997). Soil samples were collected each site-year immediately prior to planting at a depth of 0 to $20 \mathrm{~cm}$ to determine the chemical characteristics according to van Raij et al. (2001) (Table 1).

The region has a Cwa climate (tropical, with a dry winter and a hot, rainy summer) according to the Köppen classification system. Daily rainfall, irrigation, and temperatures were measured during the experimental period (Fig. 1).

The experimental design was a randomized complete block with a $2 \times 5$ factorial scheme replicated four times. The treatments consisted of two potato cultivars (Agata and Mondial) and five $\mathrm{P}$ rates $\left(0,125,250,500\right.$, and $\left.1000 \mathrm{~kg} \mathrm{P}_{2} \mathrm{O}_{5} \mathrm{ha}^{-1}\right)$ applied in the planting furrow, using triple superphosphate $\left(45 \% \mathrm{P}_{2} \mathrm{O}_{5}\right)$ as the $\mathrm{P}$ source. The plots $(4 \times 5 \mathrm{~m})$ comprised five 5-m-long rows. Only the three central rows were used for the experimental measurements; the $0.5 \mathrm{~m}$ at the end of each row and the two outer rows of each plot were ignored.

Each farmer followed his own management plan for the potato crop development cycle and was responsible for all activities associated with soil tillage, furrow treatment, irrigation, hilling, potato shoot termination, and the management of pests, weeds, and diseases.

Soil tillage consisted of two heavy disk harrowing operations, chiseling and light harrowing, which occurred on the day prior to planting. Potatoes were planted on 28 April 2011 and 17 June 2012. The furrows were mechanically opened using a furrower-planter with $0.80-\mathrm{m}$ spacing between the furrows. Fertilizers were manually applied to the furrows. In 2011, fertilization consisted of $62 \mathrm{~kg} \mathrm{~N} \mathrm{ha}^{-1}$ (ammonium sulfate, $20 \% \mathrm{~N}$ and $22 \% \mathrm{~S}$ ) and $124 \mathrm{~kg} \mathrm{~K}_{2} \mathrm{O} \mathrm{ha}$ (potassium chloride, $60 \% \mathrm{~K}_{2} \mathrm{O}$ ) applied to all plots. In 2012, $62 \mathrm{~kg} \mathrm{~N} \mathrm{ha}^{-1}$ (ammonium sulfate) and $150 \mathrm{~kg} \mathrm{~K}_{2} \mathrm{O}$ $\mathrm{ha}^{-1}$ (potassium chloride) were applied. Phosphorus fertilizer was also applied to the furrows according to the treatments. The fertilizers were manually incorporated into the soil using a hoe, and uncut seed tubers (35-g seed tubers with a diameter between 30 and $40 \mathrm{~mm}$ ) were distributed $0.30 \mathrm{~m}$ apart in the furrows. The pesticides thiamethoxam (155 g active ingredient (a.i.) ha ${ }^{-1}$ ), chlorpyrifos (557 g a.i. ha ${ }^{-1}$ ), pencycuron (280 g a.i. ha $\left.{ }^{-1}\right)$, metiram (77 g a.i. ha ${ }^{-1}$ ), fluazinam (1.155 g a.i. ha ${ }^{-1}$ ), and streptomycin (17 $\mathrm{g}$ a.i. $\left.\mathrm{ha}^{-1}\right)$ were subsequently applied. Finally, the furrows were covered manually.

The plants emerged on 14 May 2011 (16 days after planting_DAP) and 6 July 2012 (19 DAP). Sidedressing fertilizer was applied using $43 \mathrm{~kg} \mathrm{~N}^{-1}$ (urea) at $22 \mathrm{DAP}$ during the first site-year and $32 \mathrm{~kg} \mathrm{~N} \mathrm{ha}^{-1}$ (urea) and $100 \mathrm{~kg}$ $\mathrm{K}_{2} \mathrm{O} \mathrm{ha}{ }^{-1}$ (potassium chloride) at 29 DAP during the second site-year. During both site-years, thiamethoxam (150 g a.i. ha $^{-1}$ ) and fluazinam (1035 g a.i. ha ${ }^{-1}$ ) were applied simultaneously with hilling immediately after sidedressing. 
Table 1 Soil chemical and textural characteristics of the experimental areas measured prior to the potato planting

\begin{tabular}{|c|c|c|}
\hline \multirow[t]{2}{*}{ Soil characteristics } & \multicolumn{2}{|c|}{ Site-year } \\
\hline & $\begin{array}{l}\text { Avaré- } \\
2011\end{array}$ & $\begin{array}{l}\text { Taquarituba- } \\
2012\end{array}$ \\
\hline $\mathrm{pH}\left(1: 2.5\right.$ soil: $\mathrm{CaCl}_{2}$ suspension $\left.0.01 \mathrm{~mol} \mathrm{~L}^{-1}\right)$ & 5.7 & 5.6 \\
\hline Soil organic matter $\left(\mathrm{g} \mathrm{dm}^{-3}\right)$ & 47.6 & 32.4 \\
\hline $\mathrm{P}_{\text {resin-extractable }}\left(\mathrm{mg} \mathrm{dm}^{-3}\right)$ & 14 & 12 \\
\hline $\mathrm{K}\left(\mathrm{mmol}_{\mathrm{c}} \mathrm{dm}^{-3}\right)$ & 2.3 & 0.7 \\
\hline $\mathrm{Ca}\left(\mathrm{mmol}_{\mathrm{c}} \mathrm{dm}^{-3}\right)$ & 60 & 45 \\
\hline $\operatorname{Mg}\left(\mathrm{mmol}_{\mathrm{c}} \mathrm{dm}^{-3}\right)$ & 19 & 24 \\
\hline Cation exchange capacity $\left(\mathrm{mmol}_{\mathrm{c}} \mathrm{dm}^{-3}\right)$ & 108 & 110 \\
\hline Base saturation $(\%)$ & 75 & 63 \\
\hline $\mathrm{B}\left(\mathrm{mg} \mathrm{dm} \mathrm{m}^{-3}\right)$ & 0.33 & 0.28 \\
\hline $\mathrm{Cu}\left(\mathrm{mg} \mathrm{dm}^{-3}\right)$ & 8.3 & 1.4 \\
\hline $\mathrm{Fe}\left(\mathrm{mg} \mathrm{dm}^{-3}\right)$ & 60.7 & 19.7 \\
\hline $\operatorname{Mn}\left(\mathrm{mg} \mathrm{dm}^{-3}\right)$ & 24.6 & 9.1 \\
\hline $\mathrm{Zn}\left(\mathrm{mg} \mathrm{dm}{ }^{-3}\right)$ & 1.04 & 4.88 \\
\hline Sand $\left(\mathrm{g} \mathrm{kg}^{-1}\right)$ & 311 & 273 \\
\hline Silt $\left(\mathrm{g} \mathrm{kg}^{-1}\right)$ & 289 & 204 \\
\hline Clay $\left(\mathrm{g} \mathrm{kg}^{-1}\right)$ & 400 & 523 \\
\hline
\end{tabular}

In both site-years, crop management was conducted in accordance with regional cultural practices for potato crops, including sprinkler irrigation. The control of pests and diseases was accomplished using insecticides and fungicides recommended for potatoes.

Desiccation of potato shoots was performed using the herbicide diquat (331 g a.i. $\mathrm{ha}^{-1}$ ) on 18 August 2011 (112 DAP) and 24 September 2012 (99 DAP).

To examine the nutritional status of the plants, the third expanded leaf from the apex of 15 plants selected randomly from each plot was collected at 29 days after emergence (DAE) (45 DAP) in 2011 and 33 DAE (52 DAP) in 2012 (Lorenzi et al. 1997). The leaves were washed with deionized water and dried in an oven with forced-air circulation at $65{ }^{\circ} \mathrm{C}$. The dry leaves were ground to pass through a 40-mesh stainless steel screen for subsequent chemical analysis. The leaf $\mathrm{N}$ concentration was determined using $\mathrm{H}_{2} \mathrm{SO}_{4}$ (sulfuric acid) digestion and the semimicro-Kjeldahl method (Malavolta et al. 1997). Concentrations of $\mathrm{P}, \mathrm{K}, \mathrm{Ca}, \mathrm{Mg}, \mathrm{S}, \mathrm{Cu}, \mathrm{Fe}, \mathrm{Mn}$, and $\mathrm{Zn}$ were determined using atomic absorption spectrophotometry after $\mathrm{HNO}_{3}$ (nitric acid)- $\mathrm{HClO}_{4}$ (perchloric acid) digestion (Malavolta et al. 1997).
Fig. 1 Daily rainfall (), irrigation () , and maximum (D) and minimum (-) temperatures recorded at the experimental areas during the period from the April to September 2011 (a) and June to October 2012 (b) growing seasons. The planting, emergence, sidedressed fertilizer application, hilling, shoot killing, and harvest times of the potato crop are shown

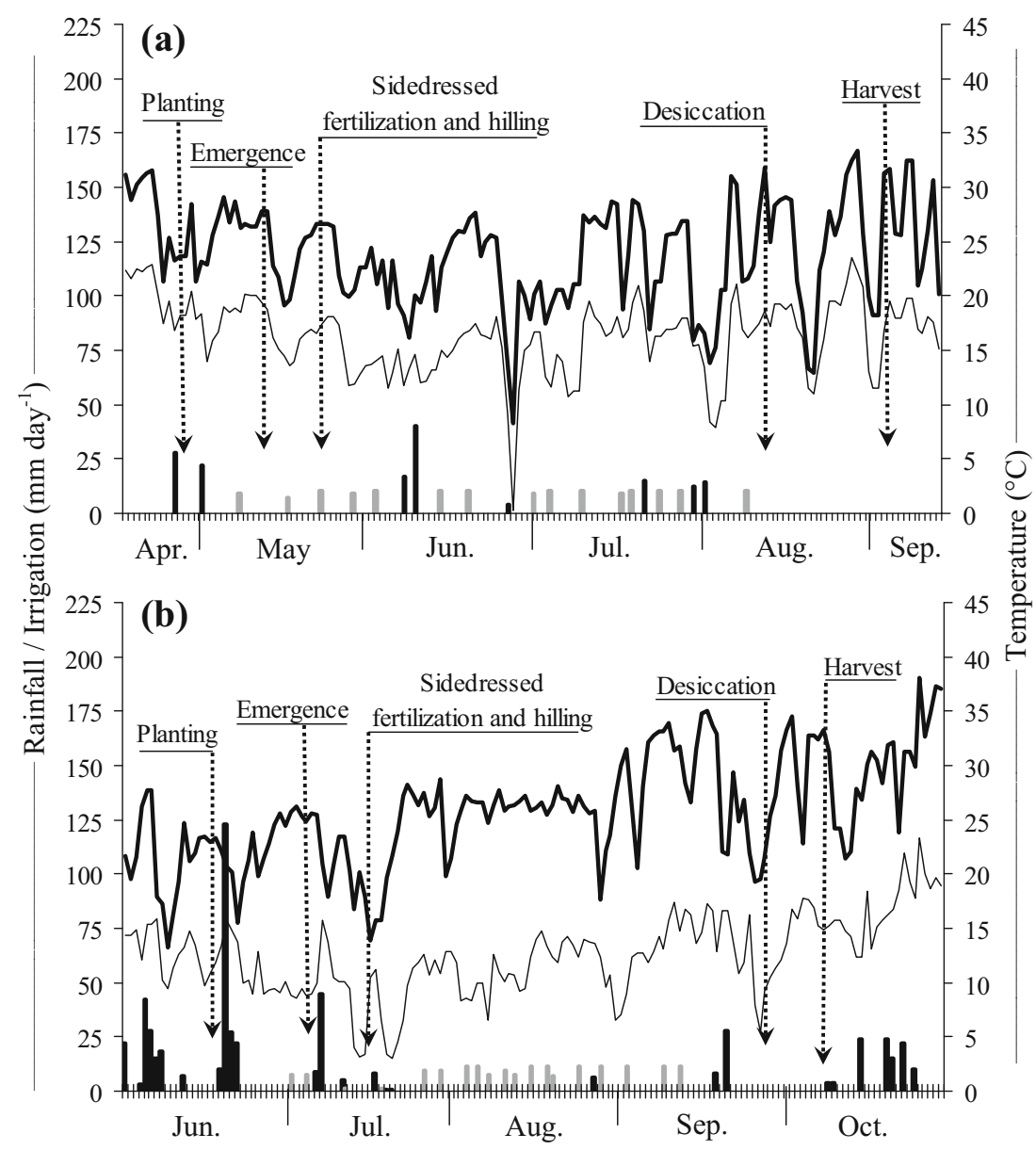


The potatoes were harvested on 4 September 2011 (129 DAP) and 10 October 2012 (115 DAP). Tubers from two 1.5 -m-long rows (10 plants) in the useful area of each plot were excavated using a spade, collected manually, and graded by size class according to the Brazilian Grade Standard, using the transverse diameter of the tubers as follows (Fernandes et al. 2011b): special $(>4.5 \mathrm{~cm})$, first $(4.5-3.3 \mathrm{~cm})$, second $(3.3-2.3 \mathrm{~cm})$, and refuse $(<2.3 \mathrm{~cm}$ and tubers with defects). After sorting, the tubers were counted and weighed to determine the number of tubers per plant, the mean tuber weight, and the tuber yield per class. The total yield was obtained by summing all tuber classes. The relative tuber yield was calculated for each $\mathrm{P}$ rate as the ratio between the tuber yield of a particular $\mathrm{P}$ rate and the maximum tuber yield.

The APUE for tuber yield was determined for each treatment by dividing the difference between the maximum tuber yield obtained in response to $\mathrm{P}$ fertilizer application and the tuber yield without $\mathrm{P}$ application by the $\mathrm{P}_{2} \mathrm{O}_{5}$ rate for the maximum tuber yield.

The data were analyzed using the SISVAR statistical software package (Ferreira 2011). The blocks and block interactions were considered as random effects. Site-year, cultivar, and the fertilizer $P$ rate were considered as fixed effects. The $F$ test was used to determine the main effects of site-year and cultivar. Regression analysis was performed to determine the fertilizer P rate response curves for several measured potato traits (dependent variables), for which significant regression equations with the highest coefficients of determination and that best explained the relationship between the $\mathrm{P}$ rates and dependent variables were selected and plotted using SigmaPlot 10.0 software (Systat Software, Inc., San Jose, CA). To analyze the significant interactions, the site-year and cultivar means were separated using Fisher's protected least significant difference (LSD) test at the 0.05 probability level and the regression equations were adjusted to the values of each cultivar separately.

Correlation coefficients were calculated between cultivars and $\mathrm{P}$ rates using STATISTICA version 6 (Statsoft, Tulsa, OK 1995) to determine the relationships between the leaf $P$ concentration and the total tuber number per plant and total mean tuber weight.

\section{Results}

\section{Leaf Nutrient Concentrations}

There was no effect of the factors site-year, cultivar, and $\mathrm{P}$ rate on the concentrations of $\mathrm{N}, \mathrm{K}, \mathrm{Ca}, \mathrm{Mg}, \mathrm{S}, \mathrm{B}, \mathrm{Cu}, \mathrm{Fe}$, and $\mathrm{Mn}$ in the third expanded leaves of the potato cultivars at 29-33 DAE, which were on average $51 \mathrm{~g} \mathrm{~kg}^{-1}$ for $\mathrm{N}, 51 \mathrm{~g} \mathrm{~kg}^{-1}$ for K, $13 \mathrm{~g} \mathrm{~kg}^{-1}$ for $\mathrm{Ca}, 7.0 \mathrm{~g} \mathrm{~kg}^{-1}$ for $\mathrm{Mg}, 2.6 \mathrm{~g} \mathrm{~kg}^{-1}$ for $\mathrm{S}$,
$26 \mathrm{mg} \mathrm{kg}^{-1}$ for $\mathrm{B}, 511 \mathrm{mg} \mathrm{kg}^{-1}$ for $\mathrm{Cu}, 397 \mathrm{mg} \mathrm{kg}^{-1}$ for $\mathrm{Fe}$, and $267 \mathrm{mg} \mathrm{kg}^{-1}$ for Mn (results not shown).

The $\mathrm{P}$ concentration in the potato leaves was affected only by the main factors, i.e., site-year, cultivar, and $\mathrm{P}$ rate (Table 2). Higher leaf $P$ concentrations were measured in Avaré-2011 compared with 2012, and the leaf P concentration of Agata was higher than that of Mondial (Table 2). The leaf $P$ concentration increased with an increase in the $\mathrm{P}$ rate up to the highest rate studied (Fig. 2a). The leaf $\mathrm{Zn}$ concentration was influenced by cultivar, the site-year $\times$ cultivar interaction and the $\mathrm{P}$ rate (Table 2). In Avaré-2011, the $\mathrm{Zn}$ concentration in the leaves of Agata was lower than that in Mondial and lower than that measured in Taquatituba-2012 (Table 3). However, Mondial had a lower leaf $\mathrm{Zn}$ concentration in Taquarituba2012 compared with Avaré-2011, but the Taquarituba-2012 leaf concentration was similar to that measured in Agata (Table 3). An increase in the P rate at planting decreased the leaf $\mathrm{Zn}$ concentration in the potato cultivars (Fig. 2b).

\section{Number and Mean Weight of Tubers}

Only the main effects of the factors (site-year, cultivar, and P rate) were significant with respect to the total number of tubers per plant and the number of tubers with a diameter larger than $45 \mathrm{~mm}$ (Table 2). In Taquarituba-2012, the total number of tubers per plant was greater than in the previous year, and Agata produced a higher total number of tubers per plant and a lower number of tubers with a diameter larger than $45 \mathrm{~mm}$. The total number of tubers per plant increased up to a rate of $250 \mathrm{~kg} \mathrm{P}_{2} \mathrm{O}_{5} \mathrm{ha}^{-1}$, but the number of tubers larger than $45 \mathrm{~mm}$ increased up to $500 \mathrm{~kg} \mathrm{P}_{2} \mathrm{O}_{5}$ ha $^{-1}$ (Fig. 2c). There was no correlation between the total number of tubers per plant and the leaf $P$ concentration (Fig. 3a).

The total mean tuber weight was significantly affected by site-year, cultivar, $\mathrm{P}$ rate, and the site-year $\times$ cultivar and cultivar $\times \mathrm{P}$ rate interactions (Table 2). Mondial exhibited a higher mean tuber weight in Avaré-2011, and in both siteyears, this variety produced tubers with a higher mean weight than Agata (Table 3). In the treatment without P fertilizer, the mean tuber weight of both cultivars was similar. However, as the $\mathrm{P}$ rate increased, Mondial produced tubers with greater weight (Fig. 2d). In both cultivars, the mean tuber weight increased up to $500 \mathrm{~kg} \mathrm{P}_{2} \mathrm{O}_{5} \mathrm{ha}^{-1}$. Regardless of cultivar, there was a positive and significant correlation between the leaf $\mathrm{P}$ concentration and the mean tuber weight (Fig. 3b).

\section{Tuber Yield, Size Distribution, and Applied P-Use Efficiency}

The total tuber yield was affected by site-year, cultivar, the rate of $\mathrm{P}$ fertilization, and the site-year $\times$ cultivar and cultivar $\times \mathrm{P}$ rate interactions, but the relative yield was influenced only by the rate of $\mathrm{P}$ (Table 4). The total tuber yield of both cultivars 
Table 2 Leaf $\mathrm{P}$ and $\mathrm{Zn}$ concentrations, tuber number per plant, and mean tuber weight of the potato crop as affected by year and cultivar, and the ANOVA significance level

\begin{tabular}{|c|c|c|c|c|c|}
\hline \multirow[t]{2}{*}{ Treatment } & \multirow{2}{*}{$\begin{array}{l}\text { Leaf } \mathrm{P} \\
\text { concentration } \\
\left(\mathrm{g} \mathrm{kg}^{-1}\right)\end{array}$} & \multirow{2}{*}{$\begin{array}{l}\text { Leaf } \mathrm{Zn} \\
\text { concentration } \\
\left(\mathrm{mg} \mathrm{kg}^{-1}\right)\end{array}$} & \multicolumn{2}{|c|}{$\begin{array}{l}\text { Tuber number per plant } \\
\text { (no. plant }^{-1} \text { ) }\end{array}$} & \multirow[t]{2}{*}{$\begin{array}{l}\text { Mean tuber weight } \\
\text { (g tuber }^{-1} \text { ) }\end{array}$} \\
\hline & & & Total & $>45 \mathrm{~mm}^{\mathrm{a}}$ & \\
\hline \multicolumn{6}{|l|}{ Site-year } \\
\hline Avaré-2011 & 3.9 & 82.1 & 6.4 & 2.2 & 79.1 \\
\hline Taquatiruba-2012 & 2.7 & 85.9 & 10.8 & 2.8 & 71.5 \\
\hline \multicolumn{6}{|l|}{ Cultivar } \\
\hline Agata & 3.5 & 78.2 & 9.4 & 2.4 & 63.0 \\
\hline Mondial & 3.1 & 89.8 & 7.8 & 2.7 & 87.6 \\
\hline \multicolumn{6}{|c|}{ ANOVA (F probability) } \\
\hline Site-year (SY) & $<0.001$ & 0.065 & $<0.001$ & $<0.001$ & $<0.001$ \\
\hline Cultivar (C) & 0.001 & $<0.001$ & $<0.001$ & 0.029 & $<0.001$ \\
\hline $\mathrm{SY} \times \mathrm{C}$ & 0.744 & $<0.001$ & 0.051 & 0.950 & 0.003 \\
\hline Phosphorus (P) & $<0.001$ & $<0.001$ & $<0.001$ & $<0.001$ & $<0.001$ \\
\hline $\mathrm{SY} \times \mathrm{P}$ & 0.401 & 0.101 & 0.991 & 0.794 & 0.063 \\
\hline $\mathrm{C} \times \mathrm{P}$ & 0.406 & 0.260 & 0.325 & 0.790 & 0.001 \\
\hline $\mathrm{SY} \times \mathrm{C} \times \mathrm{P}$ & 0.925 & 0.461 & 0.837 & 0.349 & 0.242 \\
\hline
\end{tabular}

${ }^{\mathrm{a}}$ Transverse diameter was higher in Taquarituba-2012 than in Avaré-2011 (Table 5). In Avaré-2011, Mondial achieved a higher tuber yield than Agata. In all treatments with $\mathrm{P}$ fertilization, Mondial produced a higher total tuber yield, and in both cultivars, the tuber yield increased up to $500 \mathrm{~kg} \mathrm{P}_{2} \mathrm{O}_{5} \mathrm{ha}^{-1}$ (Fig. 4a). The $500 \mathrm{~kg} \mathrm{P}_{2} \mathrm{O}_{5}$ $\mathrm{ha}^{-1}$ rate resulted in the maximum tuber yield (a relative yield
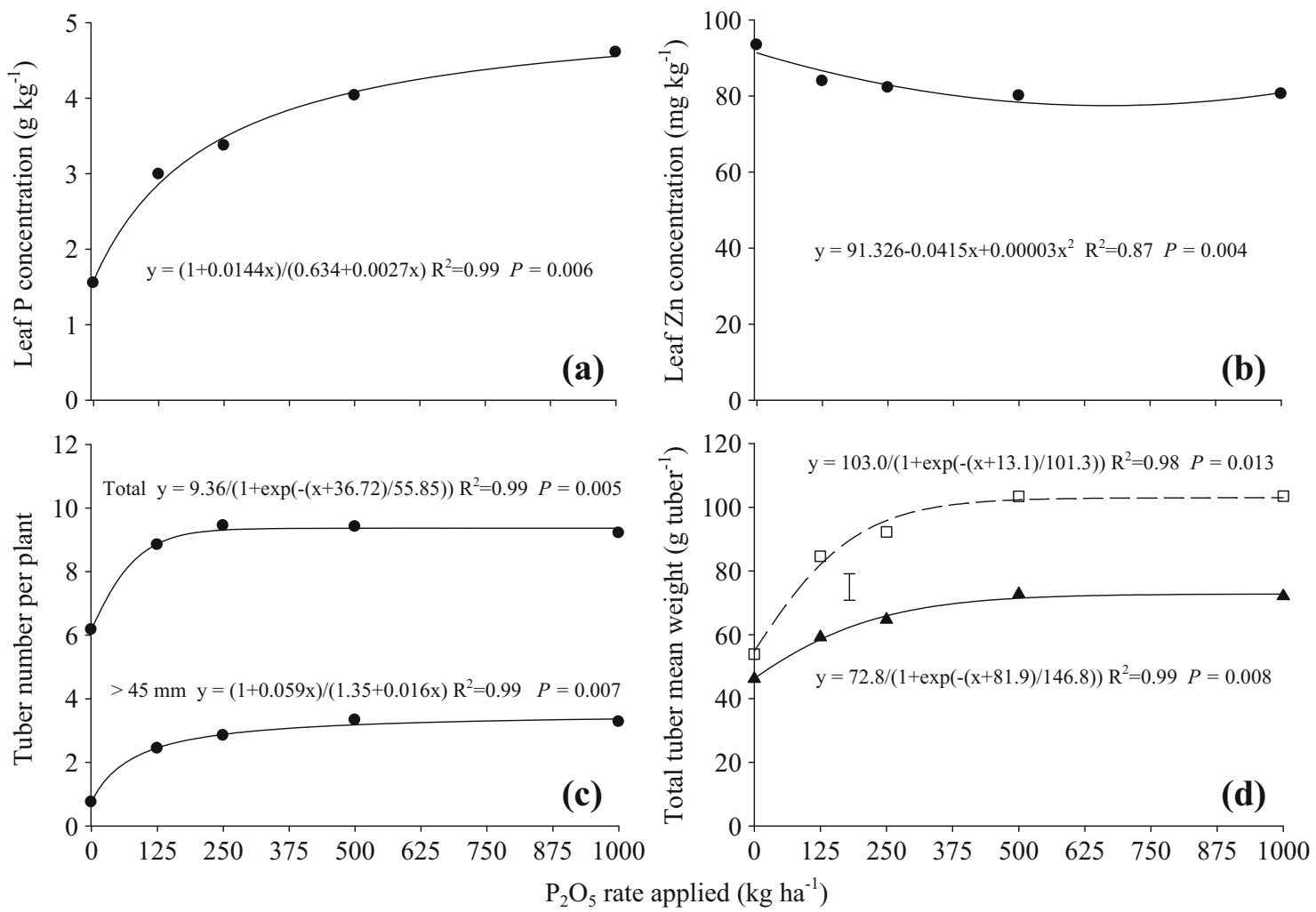

Fig. $2 \mathrm{P}$ (a) and $\mathrm{Zn}$ (b) concentration in leaves, tuber number per plant (total and with diameter $>45 \mathrm{~mm}$ ) (c), and total mean tuber weight (d) of potato as affected by $\mathrm{P}$ rate. Circles $=$ averaged over 2 years and two potato cultivars. Triangles $=$ Agata and Squares $=$ Mondial, averaged

over 2 years. Symbols represent observed values and lines are predicted values. Vertical bars represent the least significant difference at $P \leq 0.05$ according to the LSD test for cultivars subjected to the same $\mathrm{P}$ rate 
Table 3 The effects of year and cultivar on leaf Zn concentration and the total mean tuber weight of the potato crop

\begin{tabular}{lll}
\hline Site-year & Cultivar & \\
\cline { 2 - 3 } & Agata & Mondial \\
\hline & Zn concentration $\left(\mathrm{mg} \mathrm{kg}^{-1}\right)$ & $93 \mathrm{aA}$ \\
Avaré-2011 & $71 \mathrm{bB}$ & $87 \mathrm{bA}$ \\
Taquatiruba-2012 & $85 \mathrm{aA}$ & \\
Avaré-2011 & Total mean tuber weight $\left(\mathrm{g} \mathrm{tuber}^{-1}\right)$ & $94.3 \mathrm{aA}$ \\
Taquatiruba-2012 & $64.0 \mathrm{aB}$ & $80.9 \mathrm{bA}$ \\
\hline
\end{tabular}

Values followed by same lower case letter within a column and the same upper case letter within a row are not significantly different at $P \leq 0.05$ according to the LSD test of $100 \%$ ) (Fig. 4b). The relative tuber yield was less than $45 \%$ of the maximum yield when the $\mathrm{P}$ concentration in the leaves was lower than $1.5 \mathrm{~g} \mathrm{~kg}^{-1}$, but the relative tuber yield reached $90 \%$ at a $\mathrm{P}$ concentration of $2.9 \mathrm{~g} \mathrm{~kg}^{-1}$ (Fig. 5).

The site-year, cultivar, $\mathrm{P}$ rate (main effect), and cultivar $\times \mathrm{P}$ rate interaction affected the yield of tubers with diameters larger than $45 \mathrm{~mm}$ (Table 4). The greatest yield of tubers in this category occurred in Taquarituba-2012, and P fertilization
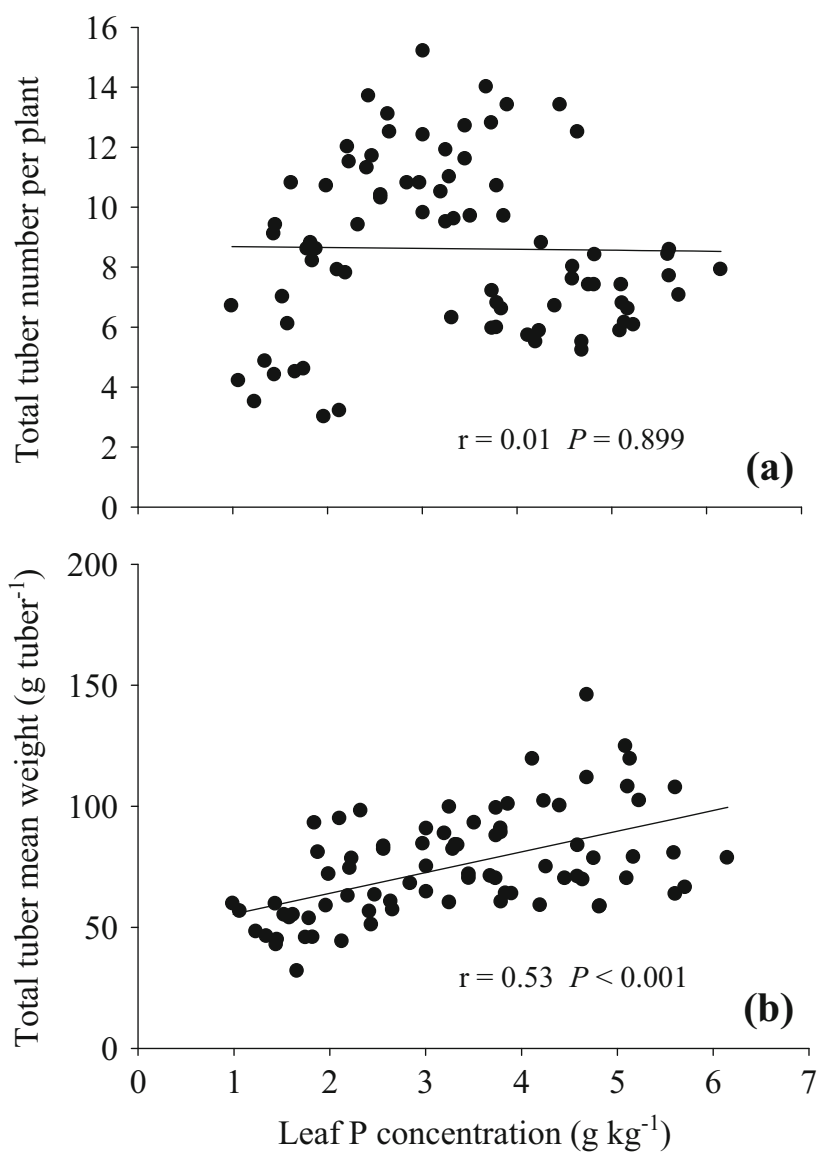

Fig. 3 The Pearson correlation coefficient $(\mathrm{r})$ and probability $(\mathrm{P})$ value for the relationship between the leaf $\mathrm{P}$ concentration and the total tuber number per plant (a) and total mean tuber weight (b) of the two potato cultivars. Symbols represent the values observed during the two years for the two potato cultivars subjected to five $\mathrm{P}$ rates, replicated four times increased the tuber yield up to the highest rate of P studied, although the most significant effects were observed up to a rate of $500 \mathrm{~kg} \mathrm{P}_{2} \mathrm{O}_{5}$ ha $^{-1}$ (Table 4 and Fig. 4c). In the treatment without $\mathrm{P}$ fertilization, the yield of the tubers that were larger than $45 \mathrm{~mm}$ in diameter did not differ and was less than $5000 \mathrm{~kg} \mathrm{ha}^{-1}$ for both cultivars. However, an increase in the $P$ rate resulted in a greater yield of this tuber class for Mondial compared with Agata (Fig. 4c).

The yield of tubers with a diameter between 45 and $33 \mathrm{~mm}$ and $<23 \mathrm{~mm}$ was affected by site-year, cultivar, P rate, and the site-year $\times$ cultivar interaction (Table 4 ). The highest yield of these tuber classes occurred in Taquarituba-2012, in which Agata had a higher yield of tubers with a diameter between 45 and $33 \mathrm{~mm}$ and a lower yield of tubers $<23 \mathrm{~mm}$ (Table 5). The yield of tubers with a diameter of $45-33 \mathrm{~mm}$ increased with an increase in the $\mathrm{P}$ rate until $250 \mathrm{~kg} \mathrm{P}_{2} \mathrm{O}_{5} \mathrm{ha}^{-1}$, and the yield of tubers $<23 \mathrm{~mm}$ decreased with an increase in $\mathrm{P}$ fertilization (Fig. $4 \mathrm{~d}$ and e).

The yield of tubers with a diameter of 33-23 mm was affected by site-year, cultivar, and the site-year $\times$ cultivar interaction (Table 4). In Taquarituba-2012, the yield of the 3323-mm-diameter tubers was higher than in Avaré-2011, and Agata produced a greater yield than Mondial, which did not occur during the previous year (Table 5).

Only the cultivar, $\mathrm{P}$ rate, and the cultivar $\times \mathrm{P}$ rate interaction significantly influenced the APUE (Table 4). For both cultivars, the APUE decreased as the $P$ rate increased, but Mondial was more efficient at a lower $\mathrm{P}$ rate compared with Agata (Fig. 4f).

\section{Discussion}

The concentrations of $\mathrm{N}, \mathrm{K}, \mathrm{Ca}, \mathrm{Mg}, \mathrm{S}, \mathrm{B}, \mathrm{Cu}, \mathrm{Fe}$, and $\mathrm{Mn}$ in the third expanded leaves of the potato cultivars of all treatments were within or higher than the adequate ranges reported by Jones Junior et al. (1991) and Lorenzi et al. (1997), indicating that the plants were not deficient in these nutrients (data not shown). 
Table 4 Total tuber yield, relative tuber yield, tuber yield distribution by size class, and applied P-use efficiency (APUE) of potato crop as affected by year and cultivar, and ANOVA significance level

\begin{tabular}{|c|c|c|c|c|c|c|c|}
\hline \multirow[t]{2}{*}{ Treatment } & \multirow{2}{*}{$\begin{array}{l}\text { Total yield } \\
\left(\mathrm{kg} \mathrm{ha}^{-1}\right)\end{array}$} & \multirow{2}{*}{$\begin{array}{l}\text { Relative yield } \\
(\%)\end{array}$} & \multicolumn{4}{|c|}{ Tuber yield by size class $\left(\mathrm{kg} \mathrm{ha}^{-1}\right)^{\mathrm{a}}$} & \multirow{2}{*}{$\begin{array}{l}\text { APUE } \\
(\mathrm{kg} \text { tuber per } \\
\left.\mathrm{kg} \mathrm{P}_{2} \mathrm{O}_{5}\right)\end{array}$} \\
\hline & & & $>45 \mathrm{~mm}$ & $45-33 \mathrm{~mm}$ & $33-23 \mathrm{~mm}$ & $<23 \mathrm{~mm}$ & \\
\hline \multicolumn{8}{|l|}{ Site-year } \\
\hline Avaré-2011 & 21,456 & 79.3 & 13,891 & 6518 & 956 & 91 & 58.3 \\
\hline Taquatiruba-2012 & 32,008 & 84.2 & 16,252 & 13,920 & 1553 & 282 & 56.3 \\
\hline \multicolumn{8}{|l|}{ Cultivar } \\
\hline Agata & 24,990 & 80.8 & 12,555 & 10,913 & 1349 & 173 & 47.1 \\
\hline Mondial & 28,474 & 82.7 & 17,589 & 9525 & 1160 & 200 & 67.6 \\
\hline \multicolumn{8}{|c|}{ ANOVA (F probability) } \\
\hline Site-year (SY) & $<0.001$ & 0.052 & $<0.001$ & $<0.001$ & $<0.001$ & $<0.001$ & 0.595 \\
\hline Cultivar (C) & $<0.001$ & 0.436 & $<0.001$ & $<0.001$ & 0.001 & 0.007 & $<0.001$ \\
\hline $\mathrm{SY} \times \mathrm{C}$ & $<0.001$ & 0.831 & 0.064 & 0.002 & 0.008 & $<0.001$ & 0.928 \\
\hline Phosphorus (P) & $<0.001$ & $<0.001$ & $<0.001$ & $<0.001$ & 0.078 & $<0.001$ & $<0.001$ \\
\hline $\mathrm{SY} \times \mathrm{P}$ & 0.967 & 0.305 & 0.344 & 0.213 & 0.081 & 0.061 & 0.798 \\
\hline $\mathrm{C} \times \mathrm{P}$ & 0.022 & 0.437 & 0.001 & 0.096 & 0.359 & 0.057 & $<0.001$ \\
\hline $\mathrm{SY} \times \mathrm{C} \times \mathrm{P}$ & 0.847 & 0.773 & 0.058 & 0.105 & 0.547 & 0.091 & 0.787 \\
\hline
\end{tabular}

${ }^{\text {a }}$ Transverse tuber diameter

The leaf $\mathrm{P}$ concentration increased similarly in both cultivars with an increasing $\mathrm{P}$ rate, which indicates that it is not necessary to evaluate the $\mathrm{P}$ nutritional status according to individual cultivars (Table 2 and Fig. 2a). In the treatments without $\mathrm{P}$ fertilization, the $\mathrm{P}$ concentration in the leaves indicated deficiency $\left(<2.5 \mathrm{~g} \mathrm{~kg}^{-1}\right)$ according to Lorenzi et al. (1997), which confirmed the low initial P availability in the

Table 5 The effects of year and cultivar on total tuber yield of the potato crop and the tuber yield distribution by size class

\begin{tabular}{|c|c|c|c|}
\hline \multirow[t]{2}{*}{ Site-year } & \multicolumn{3}{|l|}{ Cultivar } \\
\hline & Agata & & Mondial \\
\hline & & Total (kg ha-1) & \\
\hline Avaré-2011 & $18,570 \mathrm{bB}$ & & $24,342 \mathrm{bA}$ \\
\hline \multirow[t]{2}{*}{ Taquatiruba-2012 } & $31,411 \mathrm{aA}$ & & $32,605 \mathrm{aA}$ \\
\hline & & $45-33 \mathrm{~mm}\left(\mathrm{~kg} \mathrm{ha}^{-1}\right)^{\mathrm{a}}$ & \\
\hline Avaré-2011 & $6611 \mathrm{bA}$ & & $6424 \mathrm{bA}$ \\
\hline \multirow[t]{2}{*}{ Taquatiruba-2012 } & $15,216 \mathrm{aA}$ & & $12,625 \mathrm{aB}$ \\
\hline & & $33-23 \mathrm{~mm}\left(\mathrm{~kg} \mathrm{ha}^{-1}\right)^{\mathrm{a}}$ & \\
\hline Avaré-2011 & $978 \mathrm{bA}$ & & $934 \mathrm{bA}$ \\
\hline \multirow[t]{2}{*}{ Taquatiruba-2012 } & $1721 \mathrm{aA}$ & & $1386 \mathrm{aB}$ \\
\hline & & $<23 \mathrm{~mm}\left(\mathrm{~kg} \mathrm{ha}^{-1}\right)^{\mathrm{a}}$ & \\
\hline Avaré-2011 & $96 \mathrm{bA}$ & & $87 \mathrm{bA}$ \\
\hline Taquatiruba-2012 & $251 \mathrm{aB}$ & & $313 \mathrm{aA}$ \\
\hline
\end{tabular}

Values followed by same lower case letter within a column and the same upper case letter within a row are not significantly different at $P \leq 0.05$ according to the LSD test

${ }^{\text {a }}$ Transverse tuber diameter soil (Fig. 2a). However, the application of $125 \mathrm{~kg} \mathrm{P}_{2} \mathrm{O}_{5} \mathrm{ha}^{-1}$ was sufficient to increase the $\mathrm{P}$ concentration in the leaves to the adequate range reported by Lorenzi et al. (1997) (2.5 to $5.0 \mathrm{~g} \mathrm{~kg}^{-1}$ ) and Jones Junior et al. (1991) (2.9 to $\left.5.0 \mathrm{~g} \mathrm{~kg}^{-1}\right)$. In both cultivars, the $\mathrm{Zn}$ concentration in the leaves decreased with $\mathrm{P}$ fertilization up to a rate of $692 \mathrm{~kg} \mathrm{P}_{2} \mathrm{O}_{5} \mathrm{ha}^{-1}$ (Fig. 2b). According to Barben et al. (2010), $\mathrm{Zn}^{2+}$ and $\mathrm{H}_{2} \mathrm{PO}_{4}{ }^{-}$ions form chemical bonds in plant tissues and soil, and a $\mathrm{Zn}$ deficiency induced by $\mathrm{P}$ can occur under conditions of $\mathrm{P}$ excess in the soil or the plant, especially under conditions of medium and low soil $\mathrm{Zn}$ availabilities. Although $\mathrm{P}$ fertilization reduced the $\mathrm{Zn}$ concentration in the leaves in the present study, this value remained higher than the adequate range of 20 to $60 \mathrm{mg} \mathrm{kg}^{-1}$ reported for potatoes (Lorenzi et al. 1997). Barben et al. (2010) conducted a nutrient solution study and did not observe severe symptoms of $\mathrm{Zn}$ deficiency, even when an excess of $\mathrm{P}$ was supplied. Thus, we believe that the maintenance of a high $\mathrm{Zn}$ concentration in the leaves is related to the medium-high availability of this nutrient in the soil (van Raij et al. 1997) (Table 1).

There was a lower number of tubers that were larger than $45 \mathrm{~mm}$ in diameter and a lower total tuber number in Avaré2011 (Table 2), possibly because of stress caused by low temperatures and a light frost, which occurred approximately 60 DAP (Fig. 1a). Agata had a higher tuber number per plant, but the tubers had lower mean weight; the opposite effect was observed for Mondial (Tables 2 and 3). Similar results were observed by Fernandes et al. (2011b) for these cultivars. Phosphorus fertilization significantly increased the total tuber number and the number of tubers with a diameter greater than 

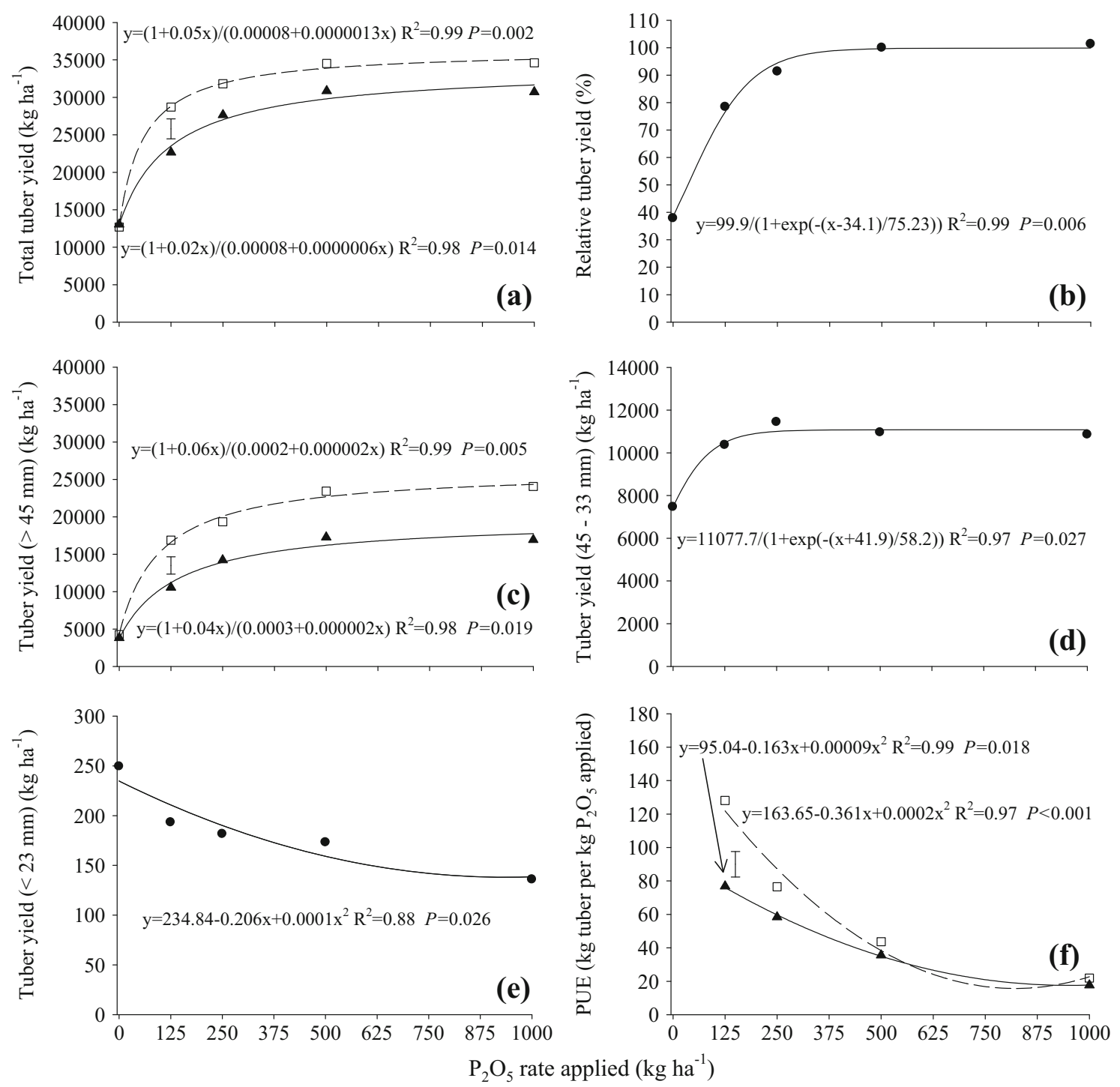

Fig. 4 Total tuber yield (a), relative tuber yield (b), tuber yield by size class (c, $\mathbf{d}$, and $\mathbf{e}$ ), and applied P-use efficiency (APUE) (f) of potato as affected by $\mathrm{P}$ rate. Circles $=$ averaged over 2 years and two potato cultivars. Triangles $=$ Agata and Squares $=$ Mondial, averaged over

$45 \mathrm{~mm}$ (Fig. 2c). This has economic implications because larger tubers have a higher commercial value. This result shows that $\mathrm{P}$ contributes to the early development of the potato crop and increases the number of larger tubers (Freeman et al. 1998; Rosen et al. 2014). Rosen and Bierman (2008) obtained a positive correlation between the tuber number per plant and the $\mathrm{P}$ concentration in the petiole of the potato plants. In our study, no significant correlation between the total tuber number per plant and the leaf $\mathrm{P}$ concentration was observed (Fig. 3a), most likely due to the continuous increase in the $\mathrm{P}$ concentration in the leaves up to the highest $\mathrm{P}$ rate supplied $\left(1000 \mathrm{~kg} \mathrm{P}_{2} \mathrm{O}_{5} \mathrm{ha}^{-1}\right)$ and the absence of an increase in the tuber number per plant with the application of $\mathrm{P}_{2} \mathrm{O}_{5}$ rates higher than $250 \mathrm{~kg} \mathrm{ha}^{-1}$ (Fig. 2a and c). This indicated that the increased $\mathrm{P}$ concentration in the leaves above the
2 years. Symbols represent observed values and lines are predicted values. Vertical bars represent the least significant difference at $P \leq 0.05$ according to the LSD test for cultivars subjected to the same phosphorus rate

minimum range limit reported by Jones Junior et al. (1991) and Lorenzi et al. (1997) had a limited effect on the tuber number per plant.

Because Mondial had a lower tuber number per plant, this cultivar allocated a larger amount of assimilated carbohydrates to tuber growth, which resulted in the formation of tubers with a larger mean weight than Agata (Tables 2 and 3). Fernandes et al. (2011b) also found that the Agata tubers had a lower mean weight than the Mondial tubers. In the absence of $\mathrm{P}$ fertilization, the mean tuber weight did not differ between cultivars, but with the application of phosphate fertilizer, Mondial showed a higher increase in the mean tuber weight compared with Agata, which resulted from the smaller tuber number per plant in Mondial (Table 2 and Fig. 2d). In a study with two potato cultivars, Freeman et al. (1998) observed that 


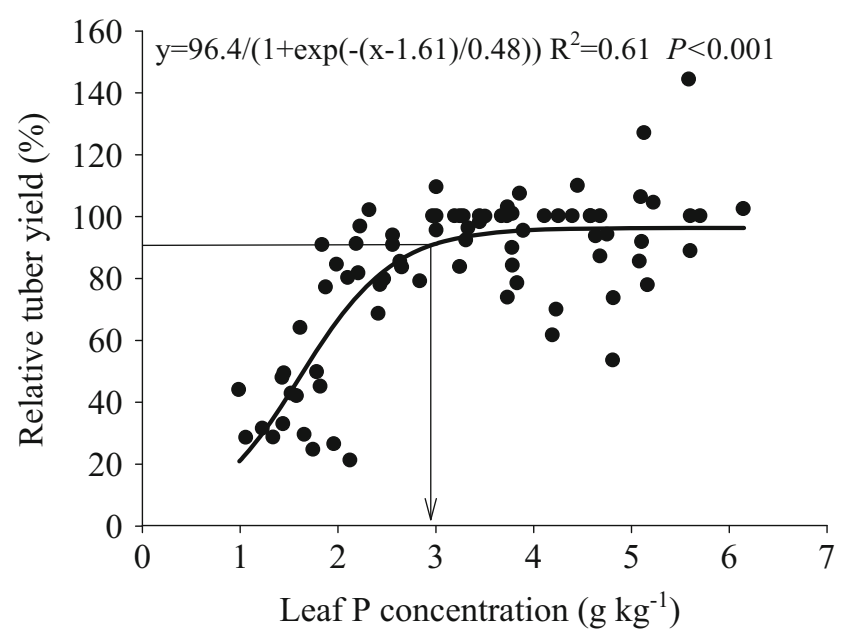

Fig. 5 Relationship between the relative tuber yield and the leaf $\mathrm{P}$ concentration. Symbols represent the values observed during the 2 years for the two potato cultivars subjected to five P rates, replicated four times

the response to $\mathrm{P}$ supply differed between the cultivars, and there was a positive effect of $\mathrm{P}$ fertilization on the mean tuber weight. In the present study, the mean tuber weight of both cultivars increased up to a rate of $500 \mathrm{~kg} \mathrm{P}_{2} \mathrm{O}_{5}$ ha $^{-1}$ (Fig. 2d), but the total tuber number per plant only increased up to $250 \mathrm{~kg} \mathrm{P}_{2} \mathrm{O}_{5}$ ha $^{-1}$ (Fig. 2c), i.e., the cultivars responded similarly to the same P rate. Dubetz and Bole (1975) also observed an increase in the mean tuber weight in response to $\mathrm{P}$ rates that were higher than those that resulted in the maximum tuber number per plant. A positive and significant correlation between the leaf $\mathrm{P}$ concentration and the mean tuber weight indicates that $\mathrm{P}$ had a greater influence on the tuber size than on the number of tubers formed (Figs. 2c, d and 3). Phosphorus plays an essential role in cellular energy transfer processes, respiration, and photosynthesis. This element is a component of nucleic acids, nucleotides, phospholipids, and phosphorylated sugars (Marschner 2012) and is important for processes related to carbohydrate formation and storage in tubers (Houghland 1960). Therefore, optimum potato plant growth and tuber bulking are achieved when the $\mathrm{P}$ demand for these functions is satisfied (Dubetz and Bole 1975; Freeman et al. 1998; Soratto et al. 2015).

The lower tuber yield observed in both cultivars in Avaré2011 occurred because of the markedly smaller number of tubers formed (Tables 2, 4, and 5). During this site-year, Mondial exhibited a higher total tuber yield because of the higher tuber number per plant, the mean tuber weight and the yield of tubers with a diameter greater than $45 \mathrm{~mm}$. Although the total tuber yield did not differ between the cultivars in Taquarituba-2012, Mondial had a higher yield of large tubers $(>45 \mathrm{~mm})$ and a lower yield of small tubers (45-33 and 33-23 mm) (Tables 4 and 5) because of the higher number of larger tubers and the higher mean tuber weight (Tables 2 and 3 and Fig. 2d).
Previous studies have suggested that a slight increase in tuber yield occurred on similar Oxisol soils at higher $\mathrm{P}$ rates $\left(>500 \mathrm{~kg} \mathrm{P}_{2} \mathrm{O}_{5} \mathrm{ha}^{-1}\right.$ ) (Fontes et al. 1997; Nava et al. 2007; Luz et al. 2013). However, our results showed that the total tuber yield of both cultivars increased only up to a rate of $500 \mathrm{~kg}$ $\mathrm{P}_{2} \mathrm{O}_{5}$ ha $^{-1}$, i.e., the rate that provided the maximum relative tuber yield (Fig. $4 \mathrm{a}$ and $\mathrm{b}$ ). This means that despite a higher $\mathrm{P}$ uptake by Mondial compared with Agata in a field environment (Fernandes et al. 2011a) and that Mondial is more responsive to $P$ availability in soil under a controlled greenhouse condition (Soratto et al. 2015), there is no reason to adjust the $P$ recommendations on an individual cultivar basis because the cultivars responded to the same $\mathrm{P}$ rate under field conditions (Fig. $4 a$ and $b$ ).

The application of $500 \mathrm{~kg} \mathrm{P}_{2} \mathrm{O}_{5} \mathrm{ha}^{-1}$ resulted in a 2.6-fold increase in the total tuber yield compared with no $\mathrm{P}$ fertilization, but a higher $\mathrm{P}$ rate did not increase the potato yield because it did not affect the number or weight of the tubers formed (Figs. 2c, $d$ and $4 a$ ). These results confirm that potatoes are highly responsive to $\mathrm{P}$ fertilization when grown in soils with low $\mathrm{P}$ availability (Table 1 ). The major tuber yield increases occurred at application rates up to $250 \mathrm{~kg} \mathrm{P}_{2} \mathrm{O}_{5}$ ha $^{-1}$, i.e., rates that also resulted in a significant increase in the tuber number and mean tuber weight (Fig. 2c, d and 4a). Other studies have also found that the highest responses in potato yield occurred at lower $P$ rates, although there is a small additional increase in potato yield at higher $\mathrm{P}$ application rates (Boock and Freire 1960; Alvarez-Sánchez et al. 1999; Fontes et al. 1997; Nava et al. 2007; Luz et al. 2013).

Although the application of as little as $125 \mathrm{~kg} \mathrm{P}_{2} \mathrm{O}_{5} \mathrm{ha}^{-1}$ increased the $\mathrm{P}$ concentration in the leaves to the adequate range reported by Lorenzi et al. (1997) (2.5 to $5.0 \mathrm{~g} \mathrm{~kg}^{-1}$ ) (Fig. 2a), the total tuber yield continued to increase up to a rate of $500 \mathrm{~kg} \mathrm{P}_{2} \mathrm{O}_{5}$ ha $^{-1}$ (Fig. 4a), and $90 \%$ of the maximum tuber yield was achieved only when the $\mathrm{P}$ concentration in the leaves was increased to $2.9 \mathrm{~g} \mathrm{~kg}^{-1}$ (Fig. 5). This means that the adequate range of 2.5 to $5.0 \mathrm{~g} \mathrm{P} \mathrm{kg}^{-1}$ suggested by Lorenzi et al. (1997) may not be suitable for all situations because in the present study, the potato yield increased with P fertilization, even when the leaf $\mathrm{P}$ concentration was within the recommended range. Thus, we suggest that the lower limit of the adequate range of leaf $\mathrm{P}$ concentration reported by Lorenzi et al. (1997) should be increased from 2.5 to $2.9 \mathrm{~g} \mathrm{~kg}^{-1}$, similar to the suggestions made by Jones Junior et al. (1991) and Martinez et al. (1999).

In the presence of $\mathrm{P}$ fertilization, the high production of larger tubers and higher mean tuber weight of Mondial were reflected in higher yields for all tuber classes and tubers larger than $45 \mathrm{~mm}$ in diameter (Figs. 2d, 4a, and c). Other authors also observed differences between potato cultivars in response to P fertilization (Freeman et al. 1998; Jenkins and Ali 1999). Our results show that $\mathrm{P}$ had a positive influence on the yield of larger tubers and a negative effect on the yield of smaller 
tubers, as evidenced by the higher number and weight of larger tubers (Table 2 and Figs. $2 \mathrm{~d}$ and $4 \mathrm{e}$ ). Similar results were observed in soil with low P availability (Boock and Freire 1960), but in soil with higher $P$ availability, $P$ fertilization increased the production of small tubers of non-marketable size (Rosen and Bierman 2008).

Differences in APUE among cultivars occurred only at lower P rates; Mondial was more efficient, as evidenced by a greater increase in tuber number, mean tuber weight and tuber yield (Table 2, Figs. 2d, 4c and f). In a controlled greenhouse experiment, Soratto et al. (2015) indicated that Agata and Mondial efficiently used the P that was taken up, but Mondial was more responsive to $\mathrm{P}$ availability in soil. According to Fernandes et al. (2014), Mondial had a greater P-uptake capacity under P-sufficient conditions because it exhibited a balance between morphological root characteristics (medium/large length and surface area) and physiological parameters (medium/high maximum influx at large concentrations $\left(\mathrm{I}_{\max }\right)$ values and net $\mathrm{P}$ influx). For $\mathrm{P}$ rates greater than $500 \mathrm{~kg} \mathrm{P}_{2} \mathrm{O}_{5} \mathrm{ha}^{-1}$, the APUE did not differ between cultivars because of tuber yield stabilization (Fig. $4 \mathrm{a}$ and f). These results show that Mondial probably has a different strategy than Agata to cope with $\mathrm{P}$ deficiency (Fernandes et al. 2014). At lower $P$ rates, Mondial had a greater tuber yield per unit of $\mathrm{P}$ applied (greater APUE) than Agata, but both cultivars increased tuber yield up to the same $\mathrm{P}$ rate.

\section{Conclusion}

In soils with low $\mathrm{P}$ availability, there is no reason to evaluate the P-nutritional status separately by cultivar because supplying $\mathrm{P}$ in the furrow resulted in a similar increase in the leaf $\mathrm{P}$ concentration in both cultivars. Phosphorus fertilization caused a similar increase in the tuber number per plant in both cultivars and resulted in a higher increase in the mean tuber weight in Mondial compared with Agata. The total tuber yield and yield of tubers larger than $45 \mathrm{~mm}$ in diameter increased up to $500 \mathrm{~kg} \mathrm{P}_{2} \mathrm{O}_{5} \mathrm{ha}^{-1}$ for both cultivars, and Mondial had a higher APUE and was more responsive than Agata to this rate. These results indicate there is no reason to adjust $\mathrm{P}$ recommendations based on cultivar because both cultivars responded to the same $\mathrm{P}$ rate $\left(500 \mathrm{~kg} \mathrm{P}_{2} \mathrm{O}_{5} \mathrm{ha}^{-1}\right)$. When the leaf $\mathrm{P}$ concentration increased above $2.9 \mathrm{~g} \mathrm{P} \mathrm{kg}^{-1}$, both cultivars exhibited a limited response to $\mathrm{P}$ fertilization. A leaf $\mathrm{P}$ concentration of $2.9 \mathrm{~g} \mathrm{P} \mathrm{kg}^{-1}$ is superior to $2.5 \mathrm{~g} \mathrm{P} \mathrm{kg}^{-1}$ as the lower limit of the $\mathrm{P}$ sufficiency range for Agata and Mondial.

Acknowledgments We would like to thank the São Paulo Research Foundation (FAPESP) for supporting this research and for providing a scholarship to the first author (Proc. 2010/04987-6). In addition, we are grateful to the National Council for Scientific and Technological Development (CNPq) for supporting this research (Proc. 480757/2010-0) and for providing an award for excellence in research to the second author.
We would also like to thank the potato grower (Grupo Ioshida) who provided the areas for this investigation and the Brazilian Association of Potato (ABBA) who provided the seed tubers.

\section{References}

Alvarez-Sánchez, E., J.D. Etchevers, J. Ortiz, R. Núñez, V. Volke, L. Tijerina, and A. Martínez. 1999. Biomass production and phosphorus accumulation of potato as affected by phosphorus nutrition. Journal of Plant Nutrition 22: 205-217.

Barben, S.A., B.G. Hopkins, V.D. Jolley, B.L. Webb, and B.A. Nichols. 2010. Phosphorus and zinc interactions in chelatorbuffered solution grown russet Burbank potato. Journal of Plant Nutrition 33: 587-601.

Boock, O.J., and E.S. Freire. 1960. Adubação da batatinha - experiências com doses crescentes de fósforo. Bragantia 19: 369-391.

Dubetz, S., and J.B. Bole. 1975. Effect of nitrogen, phosphorus and potassium fertilizers on yield components and specific gravity of potatoes. American Potato Journal 52: 399-405.

FAOSTAT. 2015. Production: crops. Food and Agriculture Organization of the United Nations. http://faostat.fao.org/site/567/default.aspx\#ancor. Accessed 22 Sept 2015.

Fernandes, A.M., R.P. Soratto, and B.L. Silva. 2011a. Extração e exportação de nutrientes em cultivares de batata: i - Macronutrientes. Revista Brasileira de Ciência do Solo 35: 2039-2056.

Fernandes, A.M., R.P. Soratto, R.M. Evangelista, B.L. Silva, and G.D. Souza-Schlick. 2011b. Produtividade e esverdeamento pós-colheita de tubérculos de cultivares de batata produzidos na safra de inverno. Revista Ciência Agronômica 42: 502-508.

Fernandes, A.M., R.P. Soratto, and J.R. Gonsales. 2014. Root morphology and phosphorus uptake by potato cultivars grown under deficient and sufficient phosphorus supply. Scientia Horticulturae 180: 190-198.

Ferreira, D.F. 2011. Sisvar: A computer statistical analysis system. Ciência e Agrotecnologia 35: 1039-1042.

Fontes, P.C.R. 1999. Batata. In Recomendações para o uso de corretivos e fertilizantes em minas gerais $-5^{a}$ Aproximação, vol 179 , eds. A.C. Ribeiro, P.T.G. Guimarães, and V.H. alvarez. Viçosa: CFSEMG.

Fontes, P.C.R., F.A.T. Rocha, and H.E.P. Martinez. 1997. Produção de máxima eficiência econômica da batata em função da adubação fosfatada. Horticultura Brasileira 15: 104-107.

Freeman, K.L., P.R. Franz, and R.W. Jong. 1998. Effect of phosphorus on the yield, quality and petiolar phosphorus concentrations of potatoes (cv. Nusset Burbank and Kennebec) grown in the krasnozem and duplex soils of Victoria. Australian Journal of Experimental Agriculture 38: 83-93.

Hopkins, B.G., D.A. Hornek, and A.E. MacGuidwin. 2014. Improving phosphorus use efficiency through potato rhizosphere modification and extension. American Journal of Potato Research 91: 161-174.

Houghland, G.V.C. 1960. The influence of phosphorus on the growth and physiology of the potato plant. American Potato Journal 37: $127-138$.

Jenkins, P.D., and H. Ali. 1999. Growth of potato cultivars in response to application of phosphate fertilizer. Annals of Applied Biology 135: 431-438.

Jones Junior, J.B., B. Wolf, and H.A. Mill. 1991. Plant analysis handbook. 213. Georgia: Micro-Macro Publishing.

Lorenzi, J.O., H.S. Miranda Filho, and B. VAN Raij. 1997. Raízes e tubérculos. In Recomendações de adubação e calagem para o Estado de São Paulo, Tech Bull 100, 2nd edn, eds. B. VAN Raij, H. Cantarella, J.A. Quaggio, and A.M.C. Furlani, 221-229. Campinas: Instituto Agronômico. 
Luz, J.M.Q., A.A. Queiroz, M. Borges, R.C. Oliveira, S.S. Leite, and R.R. Cardoso. 2013. Influence of phosphate fertilization on phosphorus levels in foliage and tuber yield of the potato cv. Agata. Semina: Ciências Agrárias 34: 649-656.

Malavolta, E., G.C. Vitti, and S.A. Oliveira. 1997. Avaliação do estado nutricional de plantas: Princípios e aplicações, 2nd edn. 319 Piracicaba: Potafos.

Marschner, P. 2012. Mineral's Nutrition of Higher Plants, vol 672, 3rd edn. San Diego: Academic.

Martinez, H.E.P., J.G. Carvalho, and R.B. Souza. 1999. Diagnose foliar. In Recomendações para o uso de corretivos e fertilizantes em minas gerais - $5^{a}$ Aproximação, eds. A.C. Ribeiro, P.T.G. Guimarães, and V.H. Alvarez, 143-168. Viçosa: CFSEMG.

Nava, G., A.R. Dechen, and V.L. Iuchi. 2007. Produção de tubérculos de batata-semente em função das adubações nitrogenada, fosfatada e potássica. Horticultura Brasileira 25: 365-370.

Ramaekers, L., R. Remans, I.M. Raoc, M.W. Blair, and J. Vanderleyden. 2010. Strategies for improving phosphorus acquisition efficiency of crop plants. Field Crops Research 117: 169-176.

Rosen, C.J., and P.M. Bierman. 2008. Potato yield and tuber set as affected by phosphorus fertilization. American Journal of Potato Research 85: $110-120$.

Rosen, C.J., K.A. Kelling, J.C. Stark, and G.A. Porter. 2014. Optimizing phosphorus fertilizer management in potato production. American Journal of Potato Research 91: 145-160.
Soratto, R.P., C. Pilon, A.M. Fernandes, and L.A. Moreno. 2015. Phosphorus uptake, use efficiency, and response of potato cultivars to phosphorus levels. Potato Research 58: 121-134.

Statsoft. 1995. STATISTICA Release 5. Tulsa: StatSoft.

Thornton, M.K., R.G. Novy, and J.C. Stark. 2014. Improving phosphorus use efficiency in the future. American Journal of Potato Research 91: $175-179$.

Tóth, G., R.A. Guicharnaud, B. Tóth, and T. Hermann. 2014. Phosphorus levels in croplands of the European Union with implications for P fertilizer use. European Journal of Agronomy 55: $42-52$.

Valladares, G.S., M.G. Pereira, and L.H.C. Anjos. 2003. Adsorção de fósforo em solos de argila de atividade baixa. Bragantia 62: 111-118.

van Raij, B., J.A. Quaggio, H. Cantarella, and C.A. Abreu. 1997. Interpretação de resultados de análise de solo. In Recomendações de adubação e calagem para o Estado de São Paulo, Tech Bull 100, 2nd edn, eds. B. VAN Raij, H. Cantarella, J.A. Quaggio, and A.M.C. Furlani, 8-13. Campinas: Instituto Agronômico.

van Raij, B., J.C. Andrade, H. Cantarella, and J.A. Quaggio. 2001. Análise química para avaliação da fertilidade de solos tropicais. 284 Campinas: ppInstituto Agronômico. 